\title{
Classification Systems with a Plot: Vessel Forms and Ceramic Typologies in the Spanish Atlantic
}

\author{
Kathryn L. Ness
}

Published online: 1 March 2015

(C) The Author(s) 2015. This article is published with open access at Springerlink.com

\begin{abstract}
The majority of current Spanish ceramics studies rely heavily on a typology based on sherds from American excavations and museum collections. While decades of use and refinement have made this system invaluable for dating sites and recognizing trade patterns in the Americas, its focus on archaeological ceramic types does little to explain how individuals used and perceived their ceramics. I argue that using a vessel-based classification system will allow archaeologists to explore deeper questions regarding behavior and emic (user-ascribed) views of the objects recovered in excavations as well as provide a way of comparing Spanish and Spanish-American ceramic assemblages.
\end{abstract}

Keywords Spain $\cdot$ Florida $\cdot$ Spanish ceramics $\cdot$ Classification systems

\section{Introduction}

In early modern Spain, people were surrounded by pottery, ranging from tiles on fountains and walls to cups and plates on tables and bacines (chamber pots) in private areas. The plethora of Spanish names for these ceramics and the specificity of some of the terms indicate the importance of pottery in Spanish culture and daily life. Indeed, current documentary research has identified over 150 different Spanish terms for ceramics (Amores Carredano and Chisvert Jiménez 1993; Lister and Lister 1976; Ramos Palencia 2010; Ruiz Gil 1999). While some of these names represent broad categories, others are for specific and comparatively rare shapes, such as alizar, a type of rectangular tile used in corner angles of walls (Lister and Lister 1976). This detailed terminology indicates how much attention early modern Spaniards paid to ceramic forms. 
The Spanish archaeological record further emphasizes the importance of ceramics, as they are the most commonly recovered artifacts. At a sixteenthto-eighteenth-century middle-class domestic site known as La Calle Corredera in Jerez de la Frontera, Spain (Fig. 1), for example, nearly $85 \%$ of the nonorganic objects inventoried are ceramic. Despite noting the pervasiveness of ceramics and studying aspects such as provenience and ware type, archaeologists have yet to fully understand the social significance of pottery to early modern Spaniards and how these items were perceived within the broader framework of household objects and luxury goods.

One possible reason for this problem is that scholars in Spain and the Americas approach this research in very different ways. In Spain, scholars focus on vessel forms while their American counterparts concentrate on archaeological ceramic types. This divergence reflects different views of archaeology on the two continents, as European archaeology is often closely allied to history while American archaeology is typically seen as a subfield of anthropology (Courtney 1999). Although both of these approaches have their strengths, the use of two different methods means that scholars are unable to compare the research being conducted on Spanish and Spanish-American sites. As a result, it is difficult to determine the extent to which Iberian cultural heritage continued to influence American cultural development long after the initial conquest.

In this article, I discuss classification systems in historical archaeology as well as the current state of Spanish ceramic studies on both sides of the Atlantic. I also introduce a new approach that uses transatlantic data and

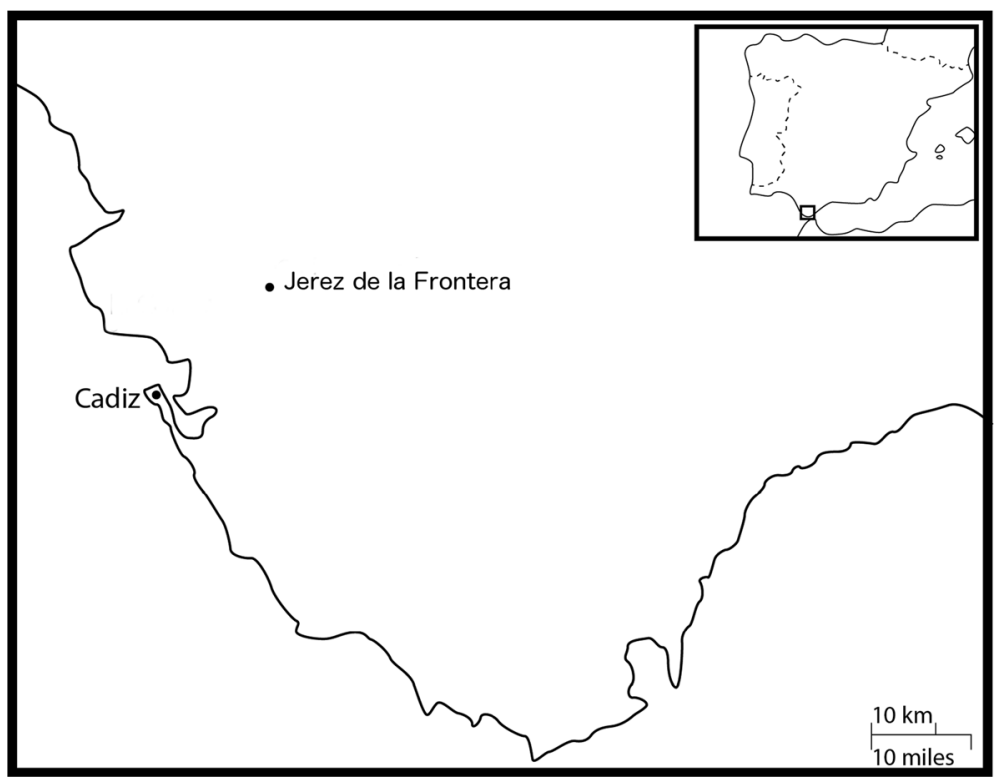

Fig. 1 Map of eastern Andalucía showing Jerez de la Frontera and Cadiz 
highlights whole vessels rather than typological details to provide a different way to understand ceramics and to bridge this academic and geographic divide.

\section{Typologies and Classification Systems in Historical Archaeology}

Since the 1910s, American scholars have debated the best method for grouping artifacts. Initial attempts at creating classification systems focused on establishing ways of identifying objects chronologically or through descriptions of their physical characteristics, such as color and material (Rice 1987; Willey and Sabloff 1980). In the 1940s and 1950s, archaeologists began to debate whether such classification systems represented culturally salient or "real" categories that were "discovered" by the analysts or whether the groupings were arbitrary and imposed on the assemblage by the researcher (Ford 1954; Spaulding 1953). Related to this debate was the question of whether or not types could be identified objectively through methods such as statistical grouping (Spaulding 1953; Whallon 1972). Today, many argue that types represent real categories, either for the archaeologist or the past consumer, although they acknowledge that these categories might not denote explicitly recognized ideals from past cultures (Beaudry et al. 1983; Rice 1987). The classification system introduced in this article is an attempt to identify such historical perspectives, in line with folk classifications based on ethnological terms and concepts (e.g., Beaudry et al. 1983; Hruby 2010; Jordan 2000).

While many archaeologists have focused on attempting to define terms and create general approaches to developing a typology (Ford 1954; Krieger 1944; Rouse 1939, 1944; Spaulding 1953; Wheat et al. 1958), others have looked at the theory behind typologies and the plethora of different approaches to organizing and classifying objects (Adams and Adams 1991; Brew 1974; Hill and Evans 1972; Read 2007; Rouse 1960; Whittaker et al. 1998). Typological method and theory have been examined in detail elsewhere (Adams and Adams 1991; Read 2007; Rice 1987; Willey and Sabloff 1980), so a comprehensive overview of this topic is unnecessary. Here, I simply explain extant classification systems pertaining to Spanish ceramics and various folk classification systems relating to ceramics more generally.

For the purposes of this article, I use Dunnell's (1971, pp. 84-85) definitions of classification systems. According to him, a taxonomic classification, or a typology, involves serially ordering and weighing classes in terms of relative importance. Similarly, Hill and Evans (1972, p. 233) define a typology as a way of grouping artifacts into distinct types based on a specific set of agreedupon physical and morphological characteristics, such as kind of clay and surface treatment. The Spanish-American ceramic typology discussed below is an example of a taxonomic classification, as it focuses on key physical characteristics that have been ordered by importance to identify and organize the sherds in question. A paradigmatic classification, in contrast, involves defining classes into categories that are not weighted in terms of relative importance but 
are ordered so as to solve a specific, stated problem (Dunnell 1971, p. 84). A folk classification that relies on ethnological descriptions, terms, and definitions of vessels could be considered a paradigmatic classification.

\section{Spanish-American Ceramic Typologies}

In the Americas, archaeologists have spent the past 50 years studying sherds recovered at sites throughout the Spanish Americas and Caribbean to create a detailed taxonomic classification that involves typological groupings based on paste, surface treatment, and decoration (Deagan 1987; FMNH 2013; Goggin 1968; McEwan 1988, 1992). These types, in turn, are typically associated with a specific date range, general manufacturing location, and set of vessel forms. It is important to note that vessel form and ceramic ware type are not mutually exclusive; one form could be made from a variety of ceramic types (e.g. plates made of coarse earthenware, majolica, or porcelain) just as one type could be made into several different vessel forms (e.g. majolica made into plates, bowls, and cups). In the five decades that scholars have used and refined this typology, it has become the standard for Spanish-American research and has been invaluable in dating sites and illuminating issues such as trade, economic trends, ceramic manufacturing locations, and cultural influences.

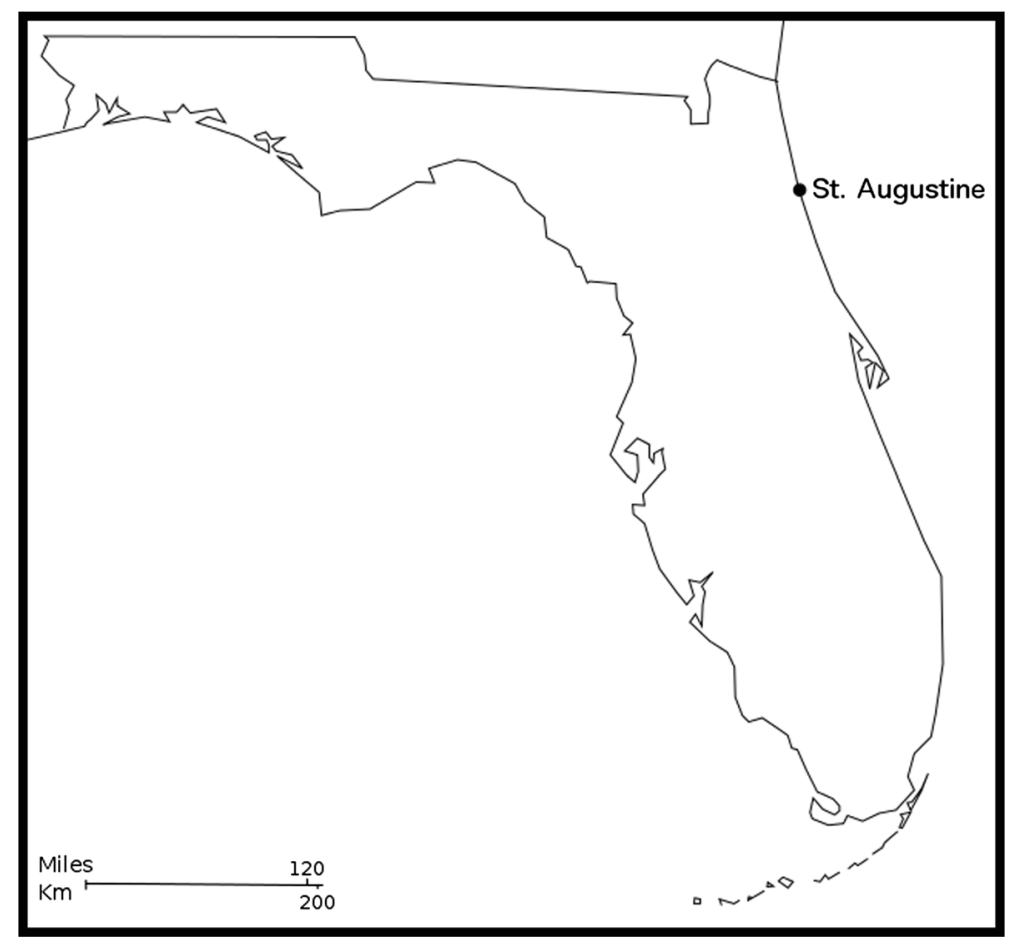

Fig. 2 Map of Florida showing St. Augustine 
The site of Palm Row in St. Augustine, Florida, is an excellent example of how this typology works (Fig. 2). Excavated in 1978, this home of relatively wealthy criollo (American-born Spaniard), Francisco Ponce de Leon, had numerous sixteenth-toeighteenth-century features, including one well and one sealed trash deposit that dates to $1762-66$. When archaeologists inventoried the ceramics from the well and trash pit, they relied on the Spanish-American typology and classified nearly all sherds, including ones measuring roughly one square centimeter, according to various types in this system. While the inventory does not include any data regarding vessel forms, sherd size, or diagnostic sherd information, it does list sherd counts and ceramic types.

By using the Spanish-American typology, archaeologists examining this site in the 1980s were able to date precisely the majority of the site's features and to ascertain where the Ponce de Leon family's ceramics were made. When they compared their findings to data from other sites in St. Augustine, they identified patterns between different socio-economic groups across town. Specifically, they found that the Ponce de Leon family had a higher percentage of majolica and a lower percentage of nonSpanish European ceramics than other, less-prominent families in town (Deagan 1983, pp. 238-239). As a result, these scholars hypothesized that certain categories of artifacts, such as tableware, could be used as socio-economic indices (Deagan 1983, pp. 238-240). They argued that households with higher incomes would have more majolica and Hispanic coarse earthenware and less indigenous and non-Spanish European ceramics while houses with lower incomes would have the reverse ratios (Deagan 1983, p. 240). Additionally, they were able to determine the percentage of Spanish versus Mexican versus British ceramics the Ponce de Leon family owned, giving scholars an idea of the global nature of the St. Augustinian economy.

This focus on ceramic types, however, has meant that scholars have yet to consider the vessel forms found at the site. As a result, it is unclear from the current inventory and studies of the site what kind of vessels the family had and how they might have used them. Did they, for example, have many serving dishes, which could suggest formal dining and entertaining? To answer such questions, one must physically reexamine and reinventory the ceramics to recover data not consistently reflected in the current typology-based inventory.

\section{Spanish Ceramic Classification Systems}

Unlike their American counterparts, Spanish archaeologists do not have a commonly accepted typology or classification system for early modern ceramics. While some Spanish scholars borrow from the typology described above, the assemblages are different enough that they cannot use it to identify all ceramics recovered in Spain. In many cases, Spaniards enjoyed vessels made from ceramic types that were not sent to the Americas, while Spanish-Americans frequently used Mexican-made majolica that was not exported to Europe. While creating a functional typology similar to the extant Spanish-American typology will be invaluable in identifying sherds recovered in Spain and refining the typology used in the Americas, it will require a larger data set from early modern Spanish sites than what is currently available. 
A relatively recent interest in moderna era (ca. 1492-ca. 1809) sites has led several Spanish archaeologists to develop classification systems based largely on vessel forms. The first such system was proposed in 1993 when archaeologists Amores Carredano and Chisvert Jiménez (1993) used objects recovered from tightly-dated architectural settings in Sevilla to identify loza común, or utilitarian vessels. Studying over 200 different vessels, the authors classified 34 distinct forms that fall into seven main categories based on their function.

A second system, introduced by José Antonio Ruiz Gil's (1999) doctoral dissertation, includes finer tableware forms and identifies 46 vessel forms, 50 kinds of decoration, and 28 manufacturing locations. The archaeologist using this system may combine these variables in multiple ways to create "types" that identify a form, decoration, and place of origin.

One can see these Spanish approaches in action at La Calle Corredera. This residential site, excavated in 2005, had numerous sixteenth-to-eighteenth-century building phases as well as several trash deposits (López Rosendo 2005a). Unlike the Palm Row site, these deposits have yet to be connected to a specific individual or family. The archaeologist who inventoried the ceramics from this site focused primarily on vessel forms, providing vessel counts rather than sherd counts and grouping objects according to their form first and ceramic type second (López Rosendo 2005b). When types are referenced in the current inventory, Spanish type names, like loza blanca, and American type names, like Columbia Plain, are often used interchangeably. Other "types" are described only vaguely, such as "blue on white" and encompass a wide variety of ceramics with different kinds of pastes, glazes, and decorations.

This vessel-based method of inventorying the ceramics illuminates behavioral changes and activities that might have occurred at the site. There are, for example, clear distinctions in tableware forms between the sixteenth-to-seventeenth-century and eighteenth-century deposits, indicating that fashions and, to some extent, foodways changed during this period and that the new trends were reflected in this community. Cooking vessels, however, seem to have remained largely the same in both size and form; while continuity in utilitarian vessels might be expected, it is interesting to note that this lack of change means that, while tableware fashions and cuisine might have transformed, cooks continued using the same kinds of vessels to prepare these new foods.

The lack of a traditional archaeological typology for early modern ceramics in Spain, however, makes it difficult to identify and study specific ware types. Archaeologists are currently unable to identify definitively where most of the ceramics from La Calle Corredera were made. As a result, they cannot answer questions regarding imported ceramics or trends between socioeconomic levels, as US archaeologists have been able to do at Palm Row in St. Augustine. Similarly, archaeologists are unable to compare the ceramics from this site to those excavated in the Americas, such as at Palm Row.

Each of these typologies and classification systems have strengths and weaknesses. The Spanish-American typology, thanks to its focus on dates and manufacturing origins, helps in dating sites and providing data on topics such as trade, economic trends, and cultural influences. By using this approach at a site like Palm Row, for example, one can date the features with a great deal of precision and say confidently 
that the family actively participated in an increasingly global trade network that included goods from England, English America, Mexico, Spain, Portugal, and Asia.

Through classifying ceramics according to their purpose, in contrast, the Spanish vessel-based approach yields information regarding specific activities and how the objects were used, which can help suggest possible user-ascribed perspectives. For a site like La Calle Corredera, this method can shed light on the activities that occurred at the site, such as cooking, entertaining, and dining.

These two case studies also illustrate the difficulties involved in trans-Atlantic comparisons. Without physically reinventorying the ceramics, it is impossible to compare the sites directly. And yet such comparisons between Spanish and SpanishAmerican sites have the potential to generate huge interpretive rewards. For example, in the case of the Ponce de Leon family, we might want to know if they followed Spanish fashions and consumption patterns. Did Spanish-Americans use the same kinds of vessels as their Spanish counterparts? Did they use them in the same ratios and perhaps in the same contexts? If so, one could conclude that Spanish heritage and trends continued to influence Spanish Americans well after the initial settlement in the New World. But in order to answer such questions, we need a system that allows us to study ceramic assemblages on both sides of the Atlantic in the same manner.

\section{Ceramic Organization in the Spanish Atlantic (COSA)}

To facilitate such research, I suggest that archaeologists employ a vessel-based classification system that uses data from both sides of the Spanish Atlantic to highlight the purpose of ceramic vessels and the activities they facilitated. For my own research on eighteenth-century domestic sites in this region, I have developed one possible such system, named Ceramic Organization in the Spanish Atlantic (COSA). In both modern and eighteenth-century Spanish, the term cosa literally translates to the word "thing," making this acronym especially appropriate for a classification system that focuses on the object or vessel form rather than the glaze, decoration, or paste type.

In structuring my classification system, I rely on the example set forth by historical archaeologists Beaudry et al. (1983) in their classification system known as The Potomac Typological System (POTS). These authors used local seventeenth- and eighteenth-century probate inventories and other historical sources to identify commonly used emic names and descriptions of vessel forms in the British colonial Chesapeake region. They then grouped individual vessel forms primarily according to vessel shape (hollow or flatware) and secondarily by function. As with Amores Carredano and Chisvert Jiménez (1993), one category, such as "jug," could contain several subtly different shapes, all of which a contemporary user would have lumped under the same name. Importantly, they did not define or illustrate rare forms, focusing primarily on common shapes that would be most useful to the average Chesapeake-area archaeologist.

In keeping with the example set forth by the authors of POTS, I relied on analyses of documentary sources, namely probate inventories, ceramic glossaries, and cookbooks, 
to identify terms and vessel forms commonly used in the sixteenth-to-eighteenth centuries (Altamiras 1758; Lister and Lister 1976; Ramos Palencia 2010, 2011). Because these sources often mention vessel forms with little to no descriptions, I have also used eighteenth-century Castilian dictionaries to provide emic descriptions of the selected terms (Real Academia Española 1726-39, 1770; 1780; 1803). In some cases, the dictionaries were remarkably specific about the shape and purpose of a vessel although they rarely mentioned how or if such objects were decorated.

It is perhaps worth noting that, while the documentary sources date to the eighteenth century, the terms themselves appear to have changed relatively little since the sixteenth century. While earlier sources do not typically include detailed descriptions, the first standardized Spanish dictionary, Diccionario de autoridades (1726-39), does include extensive descriptions as well as older terms that were used by fifteenth- and sixteenthcentury authors (Pountain 2000, p. 186). Consequently, this system, while designed to support those studying eighteenth-century sites, should also be useful for scholars working on earlier sites in the Americas. Indeed, archaeologists working with Spanish ceramics have long used many of these terms, which have been placed into a systematic framework and carefully defined below. I hope that this familiarity with the terms will result in greater comfort among those who seek to apply COSA to their own work.

Although dictionaries provide valuable physical descriptions and definitions for the terms, cookbooks are especially informative regarding connotations, frequency, and functions of different objects. As others have noted, cookbooks often indicate unexpected ways in which vessels were used and highlight the multi-purpose nature of objects such as glasses or teacups, which were sometimes used as cups, cookie-cutters, measuring tools, and so on (Scott 1997).

In the most commonly referenced eighteenth-century Spanish cookbook, Nuevo Arte de Cocina, terms and vessels tended to be multi-purpose, as recipes were often called escudilla (bowl) or plato (plate), presumably depending on the kind of vessel in which the food would be served. Stews and soups, for example, were frequently referred to as escudillas, and this term also served as a liquid measurement. Similarly, non-brothbased dishes, such as Ranas en Pastelillos, ("frogs in cakes") were often described as platos (Altamiras 1758).

Although the multi-purpose nature of terms can make it tricky to use historical texts for material culture studies, it also indicates the importance of vessel forms for early modern Spaniards and the value of considering this approach when classifying ceramics. An investigation of vessel forms can shed light on Spanish foodways from a practical standpoint, as frequent references to escudillas can indicate a stewbased diet, as well as from an emic perspective that indicates important cultural and linguistic connections between food and vessels. The individuals using the ceramics in question saw these objects in terms of how they could be used rather than how they were decorated, and they frequently relied on the same terms to identify objects, functions, and contents.

While I follow the example of POTS in using historical texts to identify and define commonly documented and recovered vessel forms, my approach differs somewhat in that I intend to group the categories primarily by their grade, or quality, and secondarily by their purpose. In both historical and modern Spanish references to ceramics, vessels are typically differentiated based on their status as común, low-grade utilitarian or 
service wares, or fino, high-quality tableware. This distinction was so important in early modern Spain and Mexico that guilds had strict requirements outlining who could produce fancy tableware vessels and who was limited to creating the more common utilitarian objects (Lister and Lister 1976, p. 18). Consequently, I make use of this emic classification and group the categories primarily according to común or fino quality.

By subdividing the forms into smaller categories based on their purpose, I aim to provide a way of showing how vessels were intended to be used. While focusing on the object's expected use can be problematic, since individuals might not have used their vessels as expected, this approach is still representative of the general mental template of a culture when it comes to identifying ceramics. Some American restaurants, for example, serve beverages in jars rather than cups or glasses, yet consumers persist in referring to the objects as jars even though they are being used for beverage consumption and not food storage. Because this activity does not leave an obvious wear mark to indicate a different use, future archaeologists might not be able to determine that these objects served an unexpected function. To account for this problem, I intend to focus on how different forms were intended to be used by considering their purpose, such as storage jars, rather than their supposed use or function, such as beverage consumption.

The smallest unit in COSA is the form itself. As mentioned above, the categories are meant to be representative of common forms mentioned in texts and identified archaeologically. In instances in which vessel terms were differentiated only by subtle features that may or may not be evident when looking at archaeological fragments, I have combined them to create one category that encompasses both forms. For example, early modern Spaniards had two terms for small pitcher-like jars that were used on tables, depending on whether the object in question had one or two handles. Because it is rare to find intact vessels and the number of handles on one vessel is often not evident from fragments, it would be almost impossible to determine conclusively whether a sherd was from a oneor a two-handled jar. To avoid misidentification, therefore, I have elected to choose one term to identify similar categories.

I wish to emphasize that this classification system is specifically designed for ceramics found on early modern (sixteenth-eighteenth centuries) Spanish-Atlantic domestic sites and therefore includes vessel forms commonly recovered from Spanish and Spanish American households that have been mentioned in texts. While some vessel forms, such as so-called "Spanish olive jars," are frequently recovered from American sites, my own research suggests that these items were rarely part of the Spanish household's assemblage. This find is in keeping with scholars who have argued that these vessels were primarily for transporting a wide variety goods and were therefore most likely not part of a typical Spanish household (Coleman and Porter 2007; Marken 1987; Smith 2010). Because several other sources provide information on these vessels and others that were intended for industrial, agricultural, and transportation purposes (Amores Carredano and Chisvert Jiménez 1993; Carruthers 2003; Goggin 1960; James 1988; Lister and Lister 1987), and because these ceramics are rarely found in household contexts in Spain, I have not included these forms in COSA.

It is also important to note that COSA relies on contemporary Spanish and SpanishAmerican terms and descriptions and, as a result, is not all-encompassing or useful for non-Spanish sites; this is very much the nature of emic or folk classifications. The following section provides both vessel categories, names, descriptions, and sketches; I 
have drawn the sketches myself to provide an idea of the appearance of the intact vessel. The measurements provided are approximate and were taken from a small number of intact or partially intact samples to provide an idea of scale. A larger sample size is necessary to accurately determine the variety of sizes and volumes of the various vessel forms listed here.

\section{Loza Común}

Food Preparation

\section{Cazuela}

A wide earthenware vessel used primarily for stewing or cooking meats, fish, eggs, or other foods over a fire without other ingredients or sauce (Real Academia Española 1726-39, 1780). Unlike the term olla, cazuela seems to have been used exclusively for the vessel form and not for the foods cooked in it.

Archaeological fragments of these vessels are typically made of coarse red earthenware with a lead glaze on the interior. Burn marks on the exterior of these vessels indicate that that they were often placed directly into the fire when they were used for cooking. One sample from La Calle Corredera in Jerez measured approximately $30 \mathrm{~cm}$ in diameter, although this form might have come in multiple sizes.

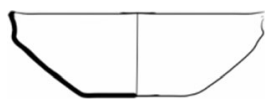

\section{Mortero}

A mortar used to crush spices, seeds, or drugs as well as a large or porous stone used to filter and sanitize water (Real Academia Española 1726-39). Eighteenth-century cookbook references to morteros typically mention crushing garlic or sugar (Altamiras 1758).

According to a study of eighteenth-nineteeth-century Castilian documents, this term was mentioned in probate inventories but does not appear to have been described (Ramos Palencia 2011, p. 51). While eighteenth-century dictionaries state that morteros were typically made of stone or wood, at least one ceramic mortar has been recovered at La Calle Corredera and shows evidence of heavy use on the interior of the base.

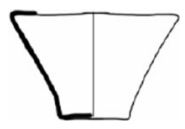

Olla

A round earthenware vessel used for cooking. Eighteenth-century dictionaries are very specific about this shape, stating that the vessels have a narrow base, 
wide belly, slightly tapered mouth, and at least one handle (Real Academia Española 1726-39). While dictionaries indicate that this term also sometimes refers to the stew made in these vessels, in cookbooks this term refers to the vessel, not its contents (Real Academia Española 1726-39; Altamiras 1758). Nueva Arte de Cocina also uses the term puchero, referring to a lead-glazed vessel that was smaller than an olla but essentially used for the same purposes (Altamiras 1758; Real Academia Española 1726-39). Because olla seems to be more generic, I have elected to use this term in COSA, although it is worth noting that there were other terms for pots. As with morteros, ollas are mentioned in early modern probate inventories but do not appear to have been described (Ramos Palencia 2011, p. 51).

According to archaeological evidence, ollas are typically made of coarse red earthenware with a lead glaze on the interior. Like cazuelas, these vessels often have evidence of burning on the exterior, indicating that they were usually placed directly in or above the fire.

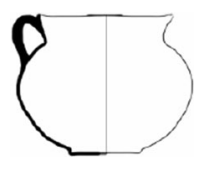

Orza

A tall, glazed earthenware jar without handles that was used for storing preserves (Real Academia Española 1726-39).

While dictionaries do not specify the size of this form or its decoration, a partially complete example was recovered from La Calle Corredera; this vessel measured approximately $16 \mathrm{~cm}$ tall and was glazed on the interior with minimal decoration on the exterior.

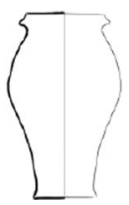

Miscellaneous Domestic Activities

\section{Lebrillo}

A round, glazed basin with flared sides and a wide mouth (Real Academia Española 1726-39, 1780). Although this form is not mentioned in Nuevo Arte de Cocina, such vessels may have been used for preparing and serving food.

Archaeological specimens of this form vary in terms of quality, paste, glaze, and decoration. Despite dictionary definitions that identify this form as a glazed vessel, decorations on archaeological examples vary widely, including undecorated, unglazed, incised, or elaborately hand painted and glazed designs. Rim decorations also vary, as some lebrillos have a flat rim that has a rectangular profile while others have a slightly 
more decorative rim with molded or impressed patterns. All have flat bases and undecorated exteriors. As a vessel form, lebrillos appear to have been all-purpose vessels, with uses ranging from preparing and serving food to bathing and laundry. I have chosen to put this form in the común category because it had a utilitarian purpose and was not strictly used as tableware.

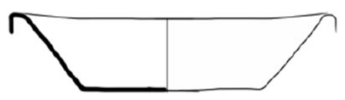

\section{Anafe}

A portable stove made from iron, earthenware, or soft stone and used most commonly in Andalucía; different forms were used depending on the material (Real Academia Española 1770, 1780).

The remains of a ceramic anafe recovered at La Calle Corredera were highly fragmentary; it was unglazed and appears to have had a base with several large holes in the sides to allow smoke to escape. No evidence was found of the upper layer where the object being heated would have rested.

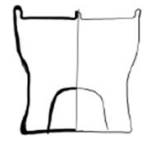

Storage and Transport

\section{Embudo}

A funnel used to channel water, wine, and other liquors (Real Academia Española 1726-39). While most embudos were probably used for liquids, at least one eighteenthcentury recipe references using a small embudo to make deviled eggs (Altamiras 1758, pp. 117-118), possibly to pipe the filling into the hardboiled eggwhite.

As with other forms in COSA, embudos are mentioned in inventories although do not appear to be described in detail (Ramos Palencia 2011, p. 49).

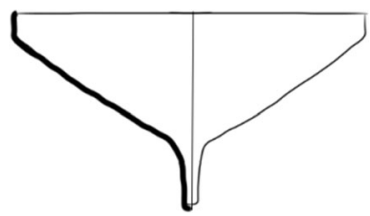

Tina

A tinaja, or a large storage jar with a wide base and narrow mouth, sometimes described as having a cauldron-like shape (Real Academia Española 1726-39, 1780). 
While archaeologists frequently use the term tinaja to describe this vessel, eighteenth-century probate inventories use the term tina (Ramos Palencia 2010, p. 52), hence my use of it here. A large, unglazed tina that measured $97 \mathrm{~cm}$ tall was found partially buried at La Calle Corredera and might have served as a cistern.

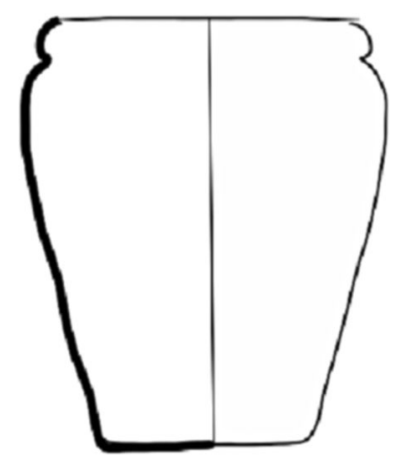

Water

\section{Arcaduz}

An earthenware bucket used to draw water from wells; this term also refers to a pipe for conducting water (Real Academia Española 1726-39, 1780).

Archaeological fragments recovered from Jerez and Sevilla indicate that these vessels were unglazed and had molded ribs on the exterior, presumably to permit attachment of a rope in order to lower the bucket into a well.

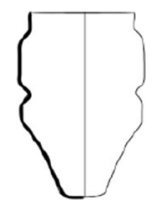

\section{Cántaro}

A large earthenware vessel with a wide belly, narrow mouth and base, and one handle, sometimes made of metal (Real Academia Española 1780). While this term is referenced in Nuevo Arte de Cocina, the vessel was typically used as a measurement for amounts of water that are more than a bowl, or escudilla (Altamiras 1758).

Some inventories use the term cantarilla (Ramos Palencia 2011, p. 47), but this term does not appear in dictionaries until 1803 (Real Academia Española 1803). Archaeologically recovered cántaros are typically made of a fine buff paste and are 
unglazed. The walls and handles are thick, suggesting the vessels were heavy and therefore used for storage and not as tableware.

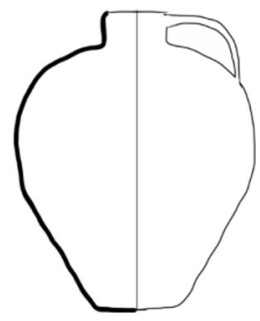

\section{Loza Fina}

Hygiene

\section{Bacin}

A chamber pot. Eighteenth-century dictionaries specify that these were round, lead glazed, and specifically for "large" human excrement (Real Academia Española 1726-39).

While one study of probate inventories suggests that the term bañado was used to identify a chamber pot (Ramos Palencia 2011, p. 46), eighteenth-century dictionaries do not use this term to denote a chamber pot or vessel having to do with human waste. Archaeological fragments of these vessels found in both Spain and the Americas indicate that they were straight sided with a broad flat rim and lead glaze on the interior. According to some scholars, the term bacin is sometimes confused with lebrillos in documents (Lister and Lister 1976, p. 56); bacines, however, served a very different purpose than lebrillos did.

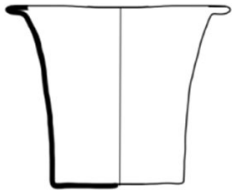

Leisure

Pipa de Tabaco

A tobacco pipe (Real Academia Española 1780).

Eighteenth-century Spanish dictionaries indicate that tobacco pipes could be made from a variety of different materials but do not specify what materials were common. 
At La Calle Corredera, for example, fragments of a Dutch white ball-clay pipes were recovered.

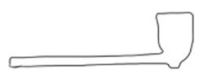

\section{Juguete}

A cheap, colorful toy, typically for children (Real Academia Española 1726-39). Because this form could have multiple shapes, ranging from miniature cooking vessels like the ones listed above to figurines, it is not possible to accurately illustrate this form.

Miniature cooking vessels and small figurines were found at La Calle Corredera, all of which had traces of thin, polychrome slip but no glaze.

Tableware: Individual

\section{Escudilla Vieja}

A bowl used for consuming soups and broths (Real Academia Española 1780). Nuevo Arte del Cocina suggests that these vessels might have also been used in cooking, especially when determining a serving (Altamiras 1758).

While eighteenth-century dictionaries use the term escudilla, archaeological examples of this form suggest that by the 1700s the shape of escudillas changed to more rounded form, thereby eliminating the straight edges and distinct angle where the body begins to narrow near the base. A partial escudilla vieja from La Calle Corredera had a diameter of $11 \mathrm{~cm}$ and was approximately $7 \mathrm{~cm}$ tall, with a $5 \mathrm{~cm}$ foot ring.

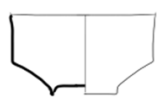

\section{Escudilla Nueva}

A bowl used for soups and broth and may have been used for cooking, serving, and consuming food, like an escudilla vieja (Altamiras 1758; Real Academia Española 1780).

Archaeological evidence indicates that this form begins to appear in the eighteenth century; it has a rounded body and a footring, similar to bowls used today. Samples from La Calle Corredera measured approximately $12 \mathrm{~cm}$ wide and $6 \mathrm{~cm}$ tall, making them similar in size to the earlier escudillas viejas. This newer form is different from what I am calling an escudilla vieja, however, in that it has a rounder body and lacks an "elbow" or angle near the base. Archaeological inventories in Spain (López Rosendo 2005b) differentiate between these two forms by calling the rounder, more modern form a cuenco and the older, angled form an escudilla. Because eighteenth-century 
texts do not differentiate between the two forms and escudilla is a very common term in eighteenth-century documents, I have chosen to add vieja and nueva to the terms to signify the different shapes. It is perhaps important to note that there are a variety of different terms for "bowl" in early modern Spanish dictionaries, including cuenco, but escudilla is the most frequently used term in contemporary texts.

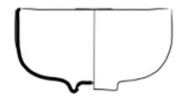

\section{Huevero}

An egg-cup on a small pedestal. In eighteenth-century dictionaries, this term is fairly generic in that it refers to anything or person that deals with or sells eggs (Real Academia Española 1780).

Although relatively rare, two partial examples were found at La Calle Corredera. One is unglazed and undecorated, while the other is tin-glazed and features a large, folded rim and blue, orange, and manganese decorations.

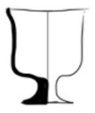

\section{Tapadera}

A lid to cover a wide-mouthed vessel, made from a variety of materials (Real Academia Española 1726-39, 1780).

This form is mentioned in inventories although it is not described in detail (Ramos Palencia 2011, p. 52). Archaeological examples from La Calle Corredera measure approximately $11 \mathrm{~cm}$ in diameter are made of a refined buff paste and appear to match the finer jarro vessels from the site.

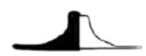

Taza

A cup for drinking and "other uses" (Real Academia Española 1780). These vessels come in various forms, including wide, bell-shaped, open, and so on. One type of cup, identified in eighteenth-century dictionaries and cookbooks as a xicara or jícara. While early modern dictionaries specify that xícaras were for drinking chocolate, cookbooks from the time period suggest cups were used for a variety of purposes, including as a dumpling mold (Altamiras 1758, pp. 110-111; Real Academia Española 1726-39, 1780).

Early modern probate inventories indicate that the terms copa and jicara also connoted cups (Ramos Palencia 2010, p. 191). Archaeological examples of tazas 
(or jicaras) are small, measuring approximately $8 \mathrm{~cm}$ tall. These vessels are typically tin-glazed cups with no handles, a footring, and a slightly flared lip. Because the term taza apparently includes the widest variety of shapes, I have elected to use this term.

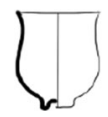

\section{Macerina}

A type of plate or saucer with a deep depression or holder in the center to fit a jicara to avoid spilling the drink (Real Academia Española 1780).

The single sherd of a macerina recovered from La Calle Corredera is tin-glazed with a thick body and a deep, straight-sided depression for the cup. Interestingly, none of the jicaras recovered at this site seem to match this sherd either in pattern or shape. Other examples from various museums suggest that this form varied in shape, thickness, and decoration.

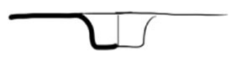

\section{Plato Viejo}

A deep plate that is almost bowl-like in shape but with a wide, flaring mouth and occasionally a marly and rim.

Archaeological examples of this form date to before the 1700s and measure approximately $22 \mathrm{~cm}$ at the widest point. They are typically made of a fine buff paste with white tin glaze (Columbia Plain in Spanish America and Loza Blanca in Spain). Because plate forms changed shape in the eighteenth century but kept the same name, I use the term plato viejo to differentiate this earlier form from its eighteenth-century successor.

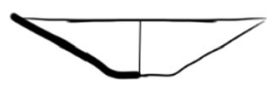

\section{Plato Nuevo}

A relatively shallow plate with a flat rim, similar to modern plate forms today. Eighteenth-century dictionaries indicate that this form was made in a variety of sizes and materials, including silver, gold, pewter, ceramic, and wood; these sources specify that it was used for serving and consuming meat. Eighteenth-century texts do not appear to have differentiated between this form and a slightly deeper form that SpanishAmerican archaeologists call a "brimmed plato."

This form begins to appear in eighteenth-century archaeological contexts and is typically made of a variety of pastes and glazes. While this form ranges in size, several 
partial samples were found at La Calle Corredera that measured $20-22 \mathrm{~cm}$ in diameter, making them similar in diameter to their predecessors. As mentioned above, I use plato nuevo to differentiate this form from earlier plate shapes.

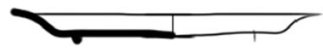

Tableware: Serving

\section{Ataifor}

A deep dish for serving meats and stews (Real Academia Española 1726-39). Late eighteenth-century dictionaries define this form as an outdated term but continue to include it (Real Academia Española 1770).

Archaeological fragments suggest that this vessel can look similar to a lebrillo, but it is generally of finer quality with thinner walls, and has a more delicate rim. One nearly complete specimen found at La Calle Corredera had a diameter of approximately $34 \mathrm{~cm}$. This form is sometimes identified as a fuente; eighteenth-century dictionaries are fairly vague as to the exact shape of fuentes, however, so I have chosen to use ataifor for this category.

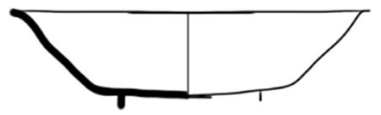

\section{Bandeja}

A slightly concave tray with a lip around the edge to hold candies, sponge cake, bread, and other foods (Real Academia Española 1770).

Eighteenth-century dictionaries define this form as a silver vessel, but archaeologists have recovered ceramic trays at La Calle Corredera. Similarly, in his analysis of probate inventories, Fernando Carlos Ramos Palencia (2010, p. 191) groups bandejas with other ceramic vessels.

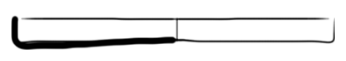

\section{Frutero}

A small basket or plate designed for displaying and serving fruit (Real Academia Española 1780).

While no specific shape is given for this term, archaeological evidence and ceramic dictionaries indicate that it had a tall, pedestal-like base (Lister and Lister 1976, p. 48; López Rosendo 2005b). The form given here is modeled after early modern still-life paintings that depict fruit in a bowl with a pedestal. Lister and Lister (1976, p. 48) also note that artificial fruits were popular table centerpieces in elite eighteenth-century 
dining rooms and suggest that fruteros were likely used as elements of centerpieces and as serving dishes.

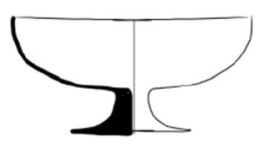

\section{Salero}

A shallow saucer-like form used for serving salt, made of a variety of materials and in a variety of shapes (Real Academia Española 1780).

Archaeological examples from La Calle Corredera measure approximately $8 \mathrm{~cm}$ in diameter and are round dishes with no foot ring and a concave area in the center for the salt. The only decoration is a greenish-white tin-glaze in the area intended to hold the salt.

Water

Jarro

A pitcher with one handle, a wide belly, narrower neck, and a spout for liquid (Real Academia Española 1780). It is important to note that the same kind of vessel with two handles is known as a jarra (Real Academia Española 1780).

Because the difference between a jarro and a jarra is often impossible to determine archaeologically unless a whole vessel is found, I have chosen to use the former term for this classification system. Both kinds of vessels appear to have a similar purpose of serving liquid at the table. Archaeological fragments found at La Calle Corredera were extremely thin, unglazed sherds with a buff paste, some with incised or molded decorations on the exterior. One semi-complete example from this site measured approximately $18 \mathrm{~cm}$ tall. Although eighteenth-century dictionaries mention that these containers were for liquor, Spanish archaeologists speculate that they were also used for water (López Rosendo 2013, personal communication).

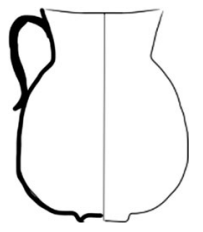

\section{Using COSA}

My preliminary analysis of Palm Row and La Calle Corredera using COSA has yielded some interesting results. At both sites, pre-eighteenth-century tableware consists of, 
among other forms, deep, bowl-like platos viejos and escudillas viejas. Eighteenthcentury features, however, contain modern, flat plates (platos nuevos) and cuencos (escudillas nuevas) of tin-glazed earthenware. These changes in vessel form coincide roughly with the Hapsburg-Bourbon dynastic transition and the rise in French fashions throughout Spain (Noyes 1998), suggesting that both Spaniards and SpanishAmericans were open to adopting specific new vessel forms in keeping with broader European trends.

In addition, both sites feature several tazas, many of which might be jicaras or cups specifically designed for consuming chocolate, and no vessels typically associated with coffee or tea. While chocolate, coffee, and tea were the most popular non-alcoholic hot beverages in eighteenth-century Spain, chocolate was by far the most commonly consumed and had been available the longest, allowing it to filter down to all levels of society (Pérez Samper 2009, pp. 25, 29, 2011, p. 130); it would have been readily available to families such as the ones that lived at Palm Row and La Calle Corredera.

These similarities are all the more noticeable when one considers that residents of St. Augustine had access to and frequently used illegal Anglo-American trade networks. The family at Palm Row had a significant amount of white salt-glazed stoneware platters and plates, which most likely came directly from England or via her American colonies. Despite being able to purchase British vessel forms like chamber pots, mugs, and tea sets, Spanish Americans in Florida appear to have selectively adopted British forms that were comparable to vessels used in Spain and rejected other forms in favor of traditional Spanish ones like lebrillos (large, shallow basins) and bacines.

Based on these findings, I hypothesize that Spanish Americans, specifically residents of St. Augustine, continued to be interested in and to copy Spanish fashions well into the eighteenth century. While they were willing to adopt some British forms and took advantage of the illicit trade networks available to them, they intentionally chose forms that were comparable to those used in Spain, like chocolate cups, and typically rejected other forms that had no Spanish equivalent or were sufficiently different, like British-shaped chamber pots or mugs. The question of precisely which "foreign" vessels they were willing to accept is an open question.

\section{“Folk Classification" Systems and Typologies}

While using a vessel-based approach is new to those working in on Spanish-Atlantic sites, it has been successfully used for several decades in a wide variety of settings ranging from early modern Anglo-America (Beaudry et al. 1983) and Dutch South Africa (Jordan 2000) to ancient Mycenae (Hruby 2010). This approach differs from the standard taxonomic classification systems discussed above in that the different groups are named according to their projected functions rather than characteristics traditionally seen as important by archaeologists, such as paste, decoration, and surface treatment (Rice 1987, p. 278).

In this respect, folk classification systems can help highlight those aspects that were considered important by the users. While archaeologists work with sherds, original consumers dealt with intact vessels (Voss and Allen 2010) and most likely purchased these items based on their shape and ability to facilitate specific activities, such as a bowl for eating soup. Often, other features such as decoration or kind of material are of secondary importance to the consumer. 
In order to understand the importance of various features, nearly all archaeologists who attempt to create a folk classification system rely on historical texts or ethnographic data. As historical archaeologist Barbara Voss (2012, p. 52) notes, "the social significance of ceramics is best investigated with reference to local historical and archaeological contexts and through integration of both documentary and archaeological evidence." By relying on the documentary record, scholars can ensure that they use categories that are representative of contemporary views of whole vessels rather than archaeologically imposed categories that have been determined from broken fragments. As a result, scholars are better able understand the social significance and emic perspectives of the recovered ceramics as well as their purpose (Beaudry et al. 1983, p. 19; Voss 2012, p. 51).

It is important to note, however, that this approach is not universally applicable and should be used with caution. Because they rely on terms and categories unique to one culture, folk classification systems are culture-specific. One cannot use the same system to study Mycenaean and Spanish or even Anglo-American and Spanish-American ceramics. Despite Spanish Americans' use of Anglo-American ceramics in places like St. Augustine, they did not use English terms or descriptions for these vessels, which renders it inappropriate for later scholars to attempt to apply POTS to organize the St. Augustinian Spanish archaeological assemblage. Consequently, a unique classification system needs to be established for each culture.

When designing a new folk classification system, one must also take into account specific cultural factors. As noted by archaeologist Prudence Rice (1987, pp. 279-282), some cultures have such a complex or non-standardized approach to classifying ceramics that culturally salient categories can be difficult to identify or replicate by outsiders. Consequently, the society in question must ideally have a fairly consistent terminology for ceramics, since regional variations and idiosyncrasies could create confusion and inaccurate identifications (Houston et al. 1989). In this respect, using the documentary record can be very helpful, as it provides a means of standardizing terms and descriptions. It also, however, means that one must be studying a literate society with a language that has been deciphered.

Fortunately, early modern Spain meets the above criteria, as it has a wealth of documentary resources and a fairly standardized, if complex, terminology for ceramics. Several scholars have identified and defined a plethora of different terms for ceramic vessels from historical texts, including household inventories, guild accounts, shipping records, and even tax documents (Amores Carredano and Chisvert Jiménez 1993; Lister and Lister 1976; Ramos Palencia 2010; Ruiz Gil 1999); these terms, however, have not been combined and organized so as to be useful for archaeologists seeking to identify artifacts until now.

\section{Conclusion}

Noted Caribbean archaeologist Irving Rouse (1960, p. 313) stated that "classification, like statistics, is not an end in itself but a technique by means of which to attain specified objectives, and so must be varied with the objective." In other words, an archaeological classification system is useful as long as it leads to insights into past behaviors by allowing scholars to answer a specific set of research questions. In some 
cases, multiple classification systems can be used on the same group of objects, like ceramics, as they enable different approaches to evaluating the data and help scholars find answers to different kinds of questions.

I wish to emphasize that folk classification systems like COSA are typically not meant to replace existing taxonomic classification systems. They are two different approaches to identifying and organizing the ceramic remains found on archaeological sites. As discussed above, both methods have their strengths and weaknesses, as they help answer very different questions and provide distinct ways of looking at and organizing artifacts. Typologies allow archaeologists to identify fragmentary objects based on their physical properties, often in a way that enables quantitative analyses, such as statistical patterning. Although this approach is often necessary when studying a new culture or building an archaeological data set for a region, it does not always yield culturally specific, qualitative information. Folk classification systems, in contrast, emphasize qualitative over quantitative research by focusing on non-physical features, such as an object's social significance or purpose. This approach allows scholars to gain a more emic perspective, but does not always lend itself to quantitative analyses and can be difficult in situations without a standardized terminology or written language.

In the case of Spanish ceramics, the existence of multiple classification systems can provide useful insights into different questions regarding the Spanish-Atlantic Empire. The current Spanish-American typology, for example, is invaluable in dating sherds and identifying their manufacturing location and, by extension, shedding light on issues such as chronology, economics, trade patterns, and cultural exchange. A folk classification system like COSA, in contrast, can yield data regarding vessel forms, daily activities, and cultural perspectives of the users of the ceramics recovered. These systems are not mutually exclusive, as they can and should be used together to obtain a more holistic view of the past.

In developing COSA, I have attempted to create a system for my own research that highlights culturally relevant aspects and therefore facilitates such qualitative research. By examining vessel forms as opposed to ware types, I am able to identify how the objects recovered at sites like La Calle Corredera and Palm Row were used and the activities the ceramics facilitated, such as drinking exotic and expensive beverages like chocolate. Additionally, the transatlantic approach inherent in COSA allows me to compare the sites in question and mitigates the challenges caused by the lack of a single transatlantic typology for Spanish ceramics. This comparison, in turn, enables me to identify cultural exchange and continuity in the Spanish Atlantic. While I designed COSA to facilitate my own research, I have taken care to construct a system with broader utility for other researchers. Consequently, COSA is meant to supplement existing typologies and provide information regarding emic perspectives on the social significance of ceramics in the Spanish Atlantic.

Currently, Spanish scholars have become increasingly interested in early modern sites in Spain while their American counterparts have begun to reevaluate how SpanishAmerican ceramics are being studied (Andalucía Dirección General de Bienes Culturales 1985-2006; Voss 2012). In this light, I hope that COSA will provide a useful foundation for future studies. As the first classification system designed to function on both sides of the Spanish Atlantic, it can help provide a means of 
comparing Spanish and Spanish-American sites while also serving as a way to explore the emic perspectives on ceramics from these areas.

As indicated by continuing research in St. Augustine and Jerez de la Frontera, using multiple classification systems has provided interesting results that could not have been obtained with only one system. While examining ceramic types allows us to identify manufacturing locations and to date sites and features, a focus on vessel forms provides insight into how the objects were used and what activities they facilitated. When used together, these two systems can help indicate specific forms that might have been introduced by foreign sources and therefore reveal cultural continuities and developments. Using a system like COSA can help shed light on these issues while also providing a direct way to compare archaeological assemblages on both sides of the Atlantic.

Acknowledgments I am indebted to quite a few people and institutions for their support with this project. First and foremost, I would like to thank Mary C. Beaudry and Amalia Perez-Juez for their help editing and advising me as I developed COSA and prepared this article. Andrea Berlin has also been invaluable in her guidance, support, and help with my research. Rosalía González Rodríguez, José Antonio Ruiz Gil, Ester López Rosendo, Francisco Barrionuevo, the Junta de Andalucia, the Museo Arqueológico de Jerez, Kathleen Deagan, Charles Cobb, Gifford J. Waters, the Florida Museum of Natural History, Carl Halbirt, and the St. Augustine Archaeological Association also deserve my deepest thanks for allowing me to study their artifacts and for sharing their research and expertise. I also would like to thank Charles E. Orser, Prudence Rice, and an anonymous reviewer for their recommendations for improving this article. Lastly, I am grateful for the financial support of a Boston University Graduate Research Abroad Fellowship and a National Science Foundation Doctoral Dissertation Research Improvement Grant (BCS-1340232), both of which made it possible to study the ceramic collections, to visit sites, museums, and research centers, and to work closely with archaeologists in Spain and Florida.

Open Access This article is distributed under the terms of the Creative Commons Attribution License which permits any use, distribution, and reproduction in any medium, provided the original author(s) and the source are credited.

\section{References}

Adams, W. Y., and Adams, E. W. (1991). Archaeological Typology and Practical Reality: A Dialectical Approach to Artifact Classification and Sorting, Cambridge University Press, Cambridge.

Altamiras, J. (1758). Nuevo Arte de Cocina Sacado de la Escuela de la Experiencia Económica su Autor. Juan de Bezáres, Barcelona.

Amores Carredano, F., and Chisvert Jiménez, N. (1993). Tipología de la cerámica común bajomedieval y moderna Sevillana (SS. XV-XVIII): I, La loza quebrada de relleno de bóvedas. Spal 2: 269-325.

Beaudry, M. C., Long, J., Miller, H., Neiman, F., and Stone, G. (1983). A vessel typology for early Chesapeake ceramics: The Potomac Typological System. Historical Archaeology 17(1): 18-43.

Brew, J. O. (1974). Archaeology of Alkali Ridge, Southeastern Utah, Kraus Reprint, New York.

Carruthers, C. (2003). Spanish "botijas" or olive jars from the Santo Domingo Monastery, La Antigua Guatemala. Historical Archaeology 37(4): 40-55.

Coleman, R. A., and Porter, A. R. D. (2007). The so-called "Spanish jars" of Jamaica and their Italian connection. Jamaica Journal 30(3): 50-61.

Courtney, P. (1999). Different strokes for different folks: the transatlantic development of historical and post medieval archaeology. In Egan, G., and Michael, R. (eds.), Old and New Worlds: Historical/Post Medieval Archaeology Papers from the Societies' Joint Conferences at Williamsburg and London 1997 to Mark Thirty Years of Work and Achievement, Oxbow Books, London, pp. 1-9.

Andalucía Dirección General de Bienes Culturales (1985-2006). Anuario arqueologico de Andalucia. Direccion general de bienes Culturales, Sevilla. 
Deagan, K. (1983). Spanish St. Augustine: The Archaeology of a Colonial Creole Community, Academic, New York.

Deagan, K. (1987). Artifacts of the Spanish Colonies of Florida and the Caribbean 1500-1800, Volume 1: Ceramics, Glassware, and Beads, Smithsonian Institution Press, Washington, DC.

Dunnell, R. (1971). Systematics in Prehistory, Free Press, New York.

FMNH (Florida Museum of Natural History). (2013). Historical Archaeology Digital Type Collection. http:// www.flmnh.ufl.edu/histarch/gallery_types/.

Ford, J. A. (1954). On the concept of types: the type concept revisited. American Anthropologist 56: 42-57.

Goggin, J. (1960). The Spanish Olive Jar: An Introductory Study, Yale University Press, New Haven.

Goggin, J. (1968). Spanish Majolica in the New World: Types of the Sixteenth to Eighteenth Centuries, Yale University Press, New Haven.

Hill, H. N., and Evans, R. K. (1972). A model for classification in typology. In Clarke, D. L. (ed.), Models in Archaeology, Methuen, London, pp. 231-274.

Houston, S., Stuart, D., and Taube, K. (1989). Folk classification of Classic Maya pottery. American Anthropologist 91: 720-726.

Hruby, J. (2010). Mycenaean pottery from Pylos: an indigenous typology. American Journal of Archaeology 114: $195-216$.

James, S. (1988). A reassessment of the chronological and typological framework of the Spanish olive jar. Historical Archaeology 22: 43-66.

Jordan, S. C. (2000). Coarse earthenware at the Dutch colonial Cape of Good Hope, South Africa: a history of local production and typology of products. International Journal of Historical Archaeology 4: 113-143.

Krieger, A. D. (1944). The typological concept. American Antiquity 9: 271-288.

Lister, F., and Lister, R. (1976). A Descriptive Dictionary for 500 Years of Spanish-Tradition Ceramics (13th through 18th Centuries), Society for Historical Archaeology, Glassboro.

Lister, F., and Lister, R. (1987). Andalucian Ceramics in Spain and New Spain: A Cultural Register from the Third Century B.C to 1700, University of Arizona Press, Tucson.

López Rosendo, E. (2005a). Arqueología de época moderna en una vivienda burguesa de Jerez de la Frontera (Cádiz): Intervención arqueológica preventiva en la C/ Corredera No. 39. In de Bienes Culturales, A. D. G. (ed.), Anuario Arqueologico de Andalucia, Direccion General de Bienes Culturales, Junta de Andalucia, Sevilla, pp. 280-294.

López Rosendo, E. (2005b). Inventario de Materiales. Ms on file, Museo Arqueológico Municipal, Jerez de la Frontera, Spain.

Marken, M. W. (1987). Pottery finds from the 1985 Atocha excavation: insights on the olive jar. Seafarers: Journal of Maritime Heritage 1: 28-31.

McEwan, B. (1988). An Archaeological Perspective of Sixteenth-Century Spanish Life in the Old World and the Americas, University Microfilms International (UMI), Ann Arbor.

McEwan, B. (1992). The role of ceramics in Spain and Spanish America in the 16th century. Historical Archaeology 26: 92-108.

Noyes, D. (1998). La Maja Vestida: dress as resistance to enlightenment in late-18th-century Madrid. Journal of American Folklore 111: 197-217.

Pérez Samper, M. (2009). La alimentación cotidiana en la Española del siglo XVIII. In García Hurtado, M. (ed.), La vida cotidiana en la España del siglo XVIII, Sílex, Madrid, pp. 11-55.

Pérez Samper, M. (2011). Mesas y cocinas en la España del siglo XVIII, Tria, Gijón.

Pountain, C. (2000). History of the Spanish Language through Texts, Routledge, London.

Ramos Palencia, F. (2010). Pautas de consumo y mercado en Castilla: 1750-1850; Economía familiar en Palencia al final del Antiguo Régimen, Silex, Madrid.

Ramos Palencia, F. (2011). Notas metodológicas sobre la utilización de los inventarios post-mortem: Clasificación de bienes de consumo, bases de datos e impacto de créditos y duedas, 1700-1850. In Muñoz Navarrao, D. (ed.), Comprar, Vender y Consumir: Nuevas Aportaciones a la Historia del Consumo en la España Moderna, Universitat de València, València, pp. 99-122.

Read, D. W. (2007). Artifact Classification: A Conceptual and Methodological Approach, Left Coast Press, Walnut Creek.

Real Academia Española. (1726-39). Diccionario de Autoridades. Nuevo Tesoro Lexicográfico de la Lengua Española, Madrid. http://ntlle.rae.es/ntlle/SrvltGUILoginNtlle.

Real Academia Española. (1770). Diccionario de Autoridades (A-B), 2nd ed. Nuevo Tesoro Lexicográfico de la Lengua Española, Madrid. http://ntlle.rae.es/ntlle/SrvltGUILoginNtlle.

Real Academia Española. (1780). Diccionario de la Lengua Castillana. Nuevo Tesoro Lexicográfico de la Lengua Española, Madrid. http://ntlle.rae.es/ntlle/SrvltGUILoginNtlle. 
Real Academia Española. (1803). Diccionario de la Lengua Castillana, 4th ed. Nuevo Tesoro Lexicográfico de la Lengua Española, Madrid. http://ntlle.rae.es/ntlle/SrvltGUILoginNtlle.

Rice, P. (1987). Pottery Analysis: A Sourcebook, University of Chicago Press, Chicago.

Rouse, I. (1939). Prehistory in Haiti: A Study in Method, Yale University Press, New Haven.

Rouse, I. (1944). On the typological method. American Antiquity 10: 202-204.

Rouse, I. (1960). The classification of artifacts in archaeology. American Antiquity 25: 313-323.

Ruiz Gil, J. A. (1999). Arqueología en la Bahía de Cádiz durante la Edad Moderna. Doctoral Dissertation, Universidad de Huelva, Huelva, Spain.

Scott, E. M. (1997). "A little gravy in the dish and onions in a tea cup": what cookbooks reveal about material culture. International Journal of Historical Archaeology 1: 131-155.

Smith, F. H. (2010). The Archaeology of Alcohol and Drinking, University Press of Florida, Gainesville.

Spaulding, A. C. (1953). Statistical techniques for the discovery of artifact types. American Antiquity 18: 350313.

Voss, B. (2012). Status and ceramics in Spanish colonial archaeology. Historical Archaeology 46(2): 39-54.

Voss, B., and Allen, R. (2010). Guide to ceramic MNV calculation qualitative and quantitative Analysis. Technical Briefs in Historical Archaeology 5: 1-9.

Whallon Jr., R. (1972). A new approach to pottery typology. American Antiquity 37: 13-33.

Wheat, J. B., Gifford, J., and Wasley, W. (1958). Ceramic variety, type cluster, and ceramic system in Southwestern pottery analysis. American Antiquity 24: 34-47.

Whittaker, J., Caulkins, D., and Kamp, K. (1998). Evaluating consistency in typology and classification. Journal of Archaeological Method and Theory 5: 129-164.

Willey, G., and Sabloff, J. (1980). A History of American Archaeology, W. H Freeman, San Francisco. 